\title{
Clinical Study of Sodium Hypochlorite, Polymyxin B And Limewater Effect on MMP-3,-8,-9 In Apical Periodontitis
}

Cláudio Antonio Talge Carvalho' ${ }^{1}$, Amjad Abu Hasna' ${ }^{\circledR}$, Alessandra Sverberi Carvalho' ${ }^{1}$, Polyana das Graças Figueiredo Vilela ${ }^{2} \oplus$, Lucas de Paula Ramos ${ }^{2} \oplus$, Marcia Carneiro Valera ${ }^{1} \oplus$, Luciane Dias de Oliveira² ${ }^{\circledR}$
This study aimed to evaluate sodium hypochlorite ( $\mathrm{NaOCI}$ ), limewater (LW), and Polymyxin $\mathrm{B}$ (PMB) as irrigants over MMP-3, MMP-8 and MMP-9. Thirty-three patients with apical periodontitis of single-rooted teeth were treated according to three-experimental groups $(n=11)$ : group $-1: 2.5 \% \mathrm{NaOCl}$ was used as irrigant; group-2: $2.5 \% \mathrm{NaOCl}$ for the first two files and $\mathrm{LW}:[0.14 \% \mathrm{Ca}(\mathrm{OH}) 2]$ for the last two files; group-3: $2.5 \% \mathrm{NaOCl}$ for the first two files and PMB for the last two files. The association of $\mathrm{Ca}(\mathrm{OH})_{2}$ and $\mathrm{CHX}$ was used as an intracanal medication in all groups. Four root canal samplings (S) were collected: S1) immediately after access cavity; S2) after biomechanical preparation; S3) after EDTA application; and S4) after removal of the intracanal medication. After quantification of MMP-3, MMP-8, and MMP-9, the data were analyzed by Friedman and Kruskal-Wallis tests and completed by Dunn test (5\%). Regardless the used irrigant, there was no difference in reducing MMP-3 or MMP-8 $(\mathrm{P}=0,5273, \mathrm{P}=0,7048$ respectively). However, in reducing MMP-9 $(\mathrm{P}=0,0246)$ the $\mathrm{NaOCl}$ group was the most effective followed by $\mathrm{NaOCl}+\mathrm{LW}$ group and $\mathrm{NaOCl}+\mathrm{PMB}$ group respectively. The intracanal medication $\left[\mathrm{Ca}(\mathrm{OH})_{2}+\mathrm{CHX}\right]$ with the $\mathrm{NaOCl}$ and $\mathrm{NaOCl}+\mathrm{LW}$ was effective in reducing MMP-8 $(\mathrm{P}<0,0001, \mathrm{P}=0,0025)$ and MMP-9 $(P=0,0007, P=0,0047)$ respectively, but not for the group of $\mathrm{NaOCl}+\mathrm{PMB}$ which was not effective in reducing MMP-8 or MMP-9 $(\mathrm{P}=0,1718, \mathrm{P}=0,1953)$ respectively. $\mathrm{NaOCl}$ and $\mathrm{NaOCl}+\mathrm{LW}$ were effective in reducing MMP-9 levels, and this effectivity could be improved by the use of the intracanal medication $\left[\mathrm{Ca}(\mathrm{OH})_{2}+\mathrm{CHX}\right]$ in reducing MMP-8 and MMP-9 levels.
'Department of Restorative Dentistry, Endodontic Division, UNESP - São Paulo State University, Institute of Science and Technology, São José dos Campos, SP, Brazil ${ }^{2}$ Department of Biosciences and Oral Diagnosis, UNESP - São Paulo State University, Institute of Science and Technology, São José dos Campos, SP, Brazil

Correspondence: Amjad Abu Hasna, Av. Francisco José Longo 777, São Dimas, 12245-000 São José dos Campos, SP, Brasil. Tel: +55-12-39479378. e-mail: d.d.s.amjad@gmail.com

Key Words: calcium hydroxide, chlorhexidine, limewater, matrix metalloproteinases, polymyxin B.

\section{Introduction}

Gram-negative bacteria is considered as the essential microbiological cause of apical periodontitis (1). It has been proven many years ago, the presence of lipopolysaccharide (LPS) in the composition of oral Gram-negative bacteria (2), which is an endotoxin considered as a potential inflammatory agent (3). LPS exists in the outer membrane of the cell wall of Gram-negative bacteria, which is released during the duplication or death of these bacteria, where it may promote various biological effects, leading to amplification of inflammatory and immunological reactions (4), including resorption of mineralized tissues (5), as well as to the development and maintenance of chronic inflammation of the periapical tissues (6).

Even more, LPSs present in infected root canals stimulate macrophages to release cytokines (IL-1 $\alpha$ and TNF- $\alpha$ ), which are responsible for the induction of matrix metalloproteinase 1 (MMP-1) synthesis, promoting periapical bone resorption (7), by initiating extracellular matrix (ECM) degradation (8).

There are twenty-four different types of MMPs (9). including MMP-3 that may contribute to periodontal connective tissue destruction, and the MMP-8 that causes unwanted tissue destruction particularly in periodontitis (10), in addition to the MMP-9 which contributes in ECM degradation in apical periodontitis lesions (8).

The periapical lesions are manifestations of periapical tissue damage, which need an endodontic treatment. However, endodontic treatment is not able to completely eliminate the micro-organisms in the root canal system (11), and thus LPS and MMPs are still present in the root canal system after the endodontic treatment $(11,12)$ reciprocating, and hybrid systems for biomechanical preparation. METHODS: Thirty single root canals with primary endodontic infection were evaluated with signs and symptoms and were randomly divided into 3 groups according to the instrumentation system used $(n=10$.

Sodium hypochlorite $(\mathrm{NaOCl})$ is an effective irrigant over Gram-negative bacteria. However, $\mathrm{NaOCl}$ is not able to disinfect the root canal system completely (11), which necessitate an extra action to complement the $\mathrm{NaOCl}$ effectivity like Polymyxin B (PMB), and limewater (LW).

PMB is a LPS specific inhibitor, and reduces MMP-1 production (7), and can alter the properties of LPS (13), and 
LW is the common name for a diluted solution of calcium hydroxide, which is also effective over LPS when associated with chlorhexidine (CHX) (14).

The aim of this study was to evaluate the effect of $\mathrm{NaOCl}, \mathrm{LW}$, and PMB as irrigants over MMP-3, MMP-8 and MMP-9. The null hypothesis was that the association of $\mathrm{NaOCl}$ with the PMB or LW, in addition to the mixed intracanal medication of $\mathrm{Ca}(\mathrm{OH})_{2}$ and $2 \% \mathrm{CHX}$ will result in low level of LPS and thus low level of MMPs in the site of periapical lesions and thus less bone destruction.

\section{Materials and Methods}

\section{Patient Selection}

After approval of the Ethics Committee of São Paulo State University, Institute of Science and Technology ICTUNESP (protocol 089/2007-PH/CEP), and all the voluntary patients signed an informed consent form. Thirty-three patients needed endodontic treatment were included in the study according to the following: 1 ) only single-rooted teeth (including superior central and lateral incisors, superior and inferior canines, and inferior premolars, however, inferior incisors were not included due to its anatomical variation and the varied diameter of the canals) diagnosed with periapical periodontitis confirmed by a negative response to sensibility tests and radiographic evidence of periapical periodontitis or visible periapical lesions (symptomatic and asymptomatic). 2) Teeth presented no periodontal disease. 3) Details of the dental history of each patient were collected. Patients with antibiotic and antifungal treatment in the past three-months or periodontal pocket exceeded $4 \mathrm{~mm}$ depth were excluded from the study. 4) Teeth that could not be isolated with a rubber dam were excluded from this study. Clinical signs and symptoms such as previous pain, tenderness to percussion and palpation, presence of a sinus tract, and exudate were recorded.

\section{Experimental Groups}

All materials and instruments used in the study were previously sterilized by cobalt- 60 gamma radiation. The teeth were isolated with a rubber dam and the operative field was disinfected with $30 \%$ hydrogen peroxide for 30 seconds, followed by $2.5 \% \mathrm{NaOCl}$ for an additional 30 seconds. $\mathrm{NaOCl}$ was neutralized then with $5 \%$ sodium thiosulfate (14).

Access cavity preparation was made with sterile pyrogenic-free high-speed burs (KG Sorensen, Cotia, SP, Brazil) under irrigation with sterile pyrogenic-free saline solution (SS). The first root canal sample (S1) was collected immediately after pulp access and before application of any antimicrobial solution. The canals were filled with SS for $1 \mathrm{~min}$. Care was taken to avoid overflow of the solution. The content was then aspirated with an insulin syringe and needle. This procedure was repeated until a final volume of $100 \mu \mathrm{L}$ was obtained (14).

According to the manufacturer instructions, EndoEze oscillating files (Ultradent Products, South Jordan, USA) were adapted to Endo-Eze contra-angle handpiece to prepare the cervical and middle thirds of the root canal by the crown-down technique. The \#15 and \#20 K-files (Dentsply-Maillefer, Ballaigues, Switzerland) were intercalated between each file of the oscillating system.

Next, cervical interferences were eliminated with the 13/.060 instrument of the Endo-Eze system using the same principles of the crown-down pressure-less technique. Instrumentation was continued using an oscillating 13/.045 file, K-file (\#15 or \#20), oscillating 13/.035 file, K-file (\#15 or \#20), and oscillating 10/.025 file until reaching a depth that was $3 \mathrm{~mm}$ shorter than the total root canal length calculated from preoperative radiographs (14).

$\mathrm{NaOCl}$ solution $(2.5 \%, 5 \mathrm{~mL})$ was used as irrigant throughout preparation of the cervical and middle root canal thirds and was renewed at each change of instrument. The working length (1 $\mathrm{mm}$ from the radiographic apex) was calculated based on a radiograph after inserting a \# $15 \mathrm{k}$-file into the root canal. To standardize the diameter of the selected teeth, only those in which the \#15 k-file could be inserted with resistance in the canal were selected.

Apical preparation (0.5 to $1 \mathrm{~mm}$ short of the radiographic apex) was performed with four K-files. As the \#15 K-file was used as initial instrument, then \#20, 25, 30, and 35 $\mathrm{K}$-files were used for the apical preparation. The teeth were then divided into three groups $(n=11)$ according to the combination of irrigants used during apical root canal preparation:

Group 1: NaOCl: $2.5 \%$ sodium hypochlorite solution;

Group 2: $\mathrm{NaOCl}+$ LW: $2.5 \%$ sodium hypochlorite, followed by limewater $\left[0.14 \% \mathrm{Ca}(\mathrm{OH})_{2}\right]$;

Group 3: $\mathrm{NaOCl}+\mathrm{PMB}: 2.5 \%$ sodium hypochlorite, followed by polymyxin B ( $10.000 \mathrm{IU} / \mathrm{mL}$, Ophtalmos Official Formulas Ltda., São Paulo, Brazil).

In group $\mathrm{NaOCl}$ (control), for the four files used, $5 \mathrm{~mL}$ of $2.5 \% \mathrm{NaOCl}$ was used as irrigant at each file change. After the last file, the canals were filled with $\mathrm{NaOCl}$, which was activated for $3 \mathrm{~min}$ (\#25 K-file) and a final irrigation with $10 \mathrm{~mL}$ of SS took place.

In group $\mathrm{NaOCl}+\mathrm{LW}, 5 \mathrm{~mL}$ of $2.5 \% \mathrm{NaOCl}$ was used for the first two apical preparations. Next, $5 \mathrm{~mL}$ of LW $\left[0.14 \% \mathrm{Ca}(\mathrm{OH})_{2}\right]$ was used as irrigant for the last two files to neutralize possible LPSs after the death of Gramnegative bacteria. After the last file, the canals were filled with LW, which was activated for $3 \mathrm{~min}$ (\#25 K-file) and a final irrigation with $10 \mathrm{~mL}$ of SS took place.

In group $\mathrm{NaOCl}+\mathrm{PMB}_{5} 5 \mathrm{~mL}$ of $2.5 \% \mathrm{NaOCl}$ was used for the first two apical preparations. Next, the canals were 
filled with PMB (10.000 IU $/ \mathrm{mL})$ and irrigated with SS for the last two files to neutralize possible LPSs after the death of Gram-negative bacteria. After the last file, the canals were filled with PMB, which was activated for 3 min (\#25 $\mathrm{K}$-file) before final irrigation with $10 \mathrm{~mL}$ of SS.

At the end of biomechanical preparation, all root canals were irrigated with $5 \mathrm{~mL}$ of SS and a second sample was collected (S2). Next, all root canals were filled with 17\% Ethylenediaminetetraacetic acid (EDTA), which was activated by a \#25 k-file for $3 \mathrm{~min}$ and then washed out with $5 \mathrm{~mL}$ of SS. A third root canal sample was then obtained (S3).

The canals were dried with sterile and pyrogenicfree absorbent paper points and filled with intracanal medication consisting of a (1:1) paste of $2 \% \mathrm{CHX}$ gel (Therapeutics Manipulation Pharmacy, SJC, SP, Brazil) and calcium hydroxide P.A. The intracanal medication was inserted into the root canals by a Lentulo spiral ran at low speed handpiece and a provisional restoration of glass ionomer cement was placed. Fourteen days after insertion of the intracanal medication, the surgical field was isolated and disinfected and the provisional restoration $10 \mathrm{~mL}$ of SS to remove the intracanal medication. The solution was aspirated and the root canal content was again collected (S4).

For completion of root canal treatment, all canals were filled with gutta-percha points (Dentsply, Petrópolis, Brazil) and AH-plus cement (Dentsply-Maillefer, Ballaigues, Switzerland) using the active lateral condensation technique. The teeth were restored with composite resin (Single Bond/Z-100, 3M ESPE, São Paulo, Brazil) and the cases will be followed up over a period of 2 years for evaluation of treatment success.

\section{Collection of Root Canal Content}

Four root canal samplings were performed: S1) immediately after crown opening; S2) after biomechanical preparation; S3) after EDTA application; and S4) after removal of the intracanal medication. All samples collected during root canal treatment $(100 \mu \mathrm{L})$ were transferred to polypropylene microtubes containing $900 \mu \mathrm{L} \mathrm{SS}$ and used for the quantification of MMP-3, MMP-8, and MMP-9.

\section{Detection and Quantification of MMP-3, MMP-8, and $M M P-9$}

MMP-3, MMP-8 and MMP-9 were quantified in the root canal samples (S1, S2, S3, and S4) by ELISA using the anti-MMP-3, anti-MMP-8 and anti-MMP-9 DuoSet kits (R\&D Systems, Minneapolis, MN, USA) according to manufacturer instructions. After determination of optical densities, the levels of MMP-3, MMP-8 and MMP-9 (pg/
$\mathrm{mL}$ ) were calculated using the GraphPad Prism 5.0 program.

\section{Statistical Analysis}

The data were subjected to the normality test and then compared the percent reduction in MMP levels among samples of the same experimental group by Friedman test followed by Dunn test (5\%) for multiple comparison, and among the experimental groups by Kruskal-Wallis followed by Dunn tests (5\%).

\section{Results}

Table. 1 presents the median and homogenous groups of MMP-3, MMP-8, MMP-9 in samples (S1, S2, S3, and S4).

Regardless the used irrigant, there was no difference in reducing MMP-3 or MMP-8 $(\mathrm{P}=0.5273, \mathrm{P}=0.7048$ respectively). However, in reducing MMP-9 $(P=0.0246)$ the $\mathrm{NaOCl}$ group was the most effective followed by $\mathrm{NaOCl}+$ $\mathrm{LW}$ group and $\mathrm{NaOCl}+\mathrm{PMB}$ group respectively.

The application of $17 \%$ EDTA was not effective in all experiment groups in terms of reducing MMPs levels. However, it was effective in reducing MMP-8 levels when used after the $\mathrm{NaOCl}$, or $\mathrm{NaOCl}+\mathrm{LW}$, but not for $\mathrm{NaOCl}$ + PMB.

On the other hand, the association of the intracanal medication $\left[\mathrm{Ca}(\mathrm{OH})_{2}+\mathrm{CHX}\right]$ with the $\mathrm{NaOCl}$ and $\mathrm{NaOCl}+$ LW was effective in reducing MMP-8 $(P<0,0001, P 0,0025)$ and MMP-9 $(P=0,0007, P=0,0047)$, but not for the group of $\mathrm{NaOCl}+\mathrm{PMB}$ which was not effective in reducing MMP-8 or MMP-9 $(\mathrm{P}=0,1718, \mathrm{P}=0,1953)$.

The association of the intracanal medication $\left[\mathrm{Ca}(\mathrm{OH})_{2}\right.$ $+\mathrm{CHX}]$ with any other irrigant of the experiment groups was not effective in reducing MMP-3 levels $(\mathrm{NaOCl} P=$ $0,1386, \mathrm{NaOCl}+$ LW P=0,5168, $\mathrm{NaOCl}+\mathrm{PMBP}=0,7968)$.

\section{Discussion}

Despite of its effectivity over Gram-negative microorganisms (11), $\mathrm{NaOCl}$ has a little action over LPS $(15,16)$. In the present study, the effects of $2.5 \% \mathrm{NaOCl}$ alone or when associated with $0.14 \%$ LW or PMB as irrigants were evaluated during the biomechanical preparation of root canals with necrotic pulp and periapical lesions in order to evaluate their effect over MMPs. The use of $L W$ and PMB has been shown to be important in the neutralization of LPSs when used in anterior studies (14-16).

In the present study $2.5 \% \mathrm{NaOCl}$ was used to start the biomechanical preparation and LW or PMB for the preparation with the last two instruments in order to try to increase the neutralization of LPSs during the preparation of the root canals and thus less MMPs synthesis.

The positive correlation between LPS and MMPs make it difficult to study MMPs without studying LPS. LPS is an endotoxin that exists in the outer membrane of the cell 


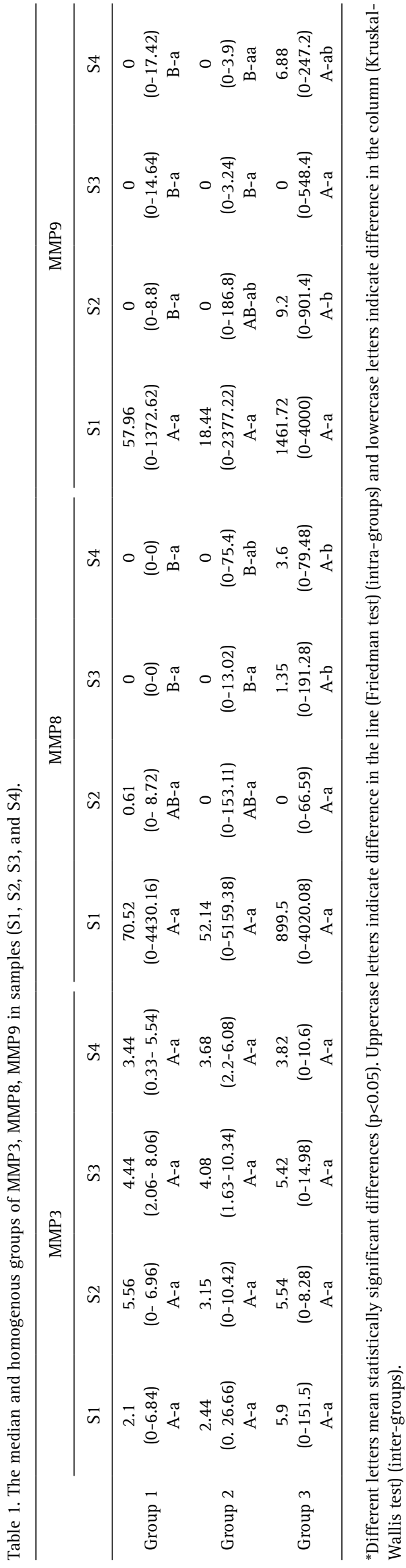

wall of Gram-negative micro-organisms and as a response for the antimicrobial action of irrigants or intracanal medications over these Gram-negative micro-organisms, LPS becomes liberated during the micro-organism death (4). As a result, LPS stimulates macrophages to release cytokines (IL-1 $\alpha$ and TNF- $\alpha$ ), which are responsible for the induction of MMP-1 synthesis, promoting periapical bone resorption (7), by initiating ECM degradation (8). This positive correlation means theoretically that, the least the LPS level in the root canal system is, the least the MMPs level is.

In the present study, one MMP of the three main subgroups was selected in order to determine the role of different MMPs in periapical changes that occur in teeth with pulp necrosis, and to monitor the decline in MMPs levels during root canal treatment: a collagenase (MMP-8) which degrades fibrillar collagen, a gelatinase (MMP-9) which specifically degrades type IV collagen and fibronectin, and a stromelysin (MMP-3) which degrades different extracellular matrix components such as proteoglycans, laminin, fibronectin, and amorphous collagen.

MMP-3 levels were low in all samples, irrespective of the experiment group. These findings indicate that MMP3 is not a suitable marker for monitoring the response to root canal treatment since no important relationship was observed between the amount of this MMP in the first and last sampling. Few studies have evaluated the expression and activity of MMP-3 in pulpal and periapical tissues, a fact impairing the discussion of these results. Gusman et al. (17) reported significantly lower levels of MMP-2 and MMP-3 in symptomatic pulpitis versus healthy pulps. In contrast, a more recent study founded a positive correlation between the presence of MMP-3 and the periapical lesions (18). Different results for MMP-3 levels have been reported in these studies in which cell lines were stimulated with LPS from different microorganisms as occurs in endodontic infections.

The differences between these few studies evaluating MMP-3 might be due to the complex mechanisms underlying the production and release of different MMPs. The expression of these enzymes is influenced by numerous factors through $\mathrm{PGE}_{2}$-dependent or -independent pathways (via COX-2). Growth factors, hormones, microbial factors, balance between MMPs and tissue inhibitors (TIMPs), cytokines, and chemical mediators can interfere positively or negatively with the production of MMPs $(7,10,12,19)$.

In a recent systematic review, studying the irreversible pulpits, concluded that MMP-9 detected in both gene and protein levels during the inflammation (20). However, In the present study, unlike MMP-3, the sample 1 of teeth with pulp necrosis and apical periodontitis presented high levels of MMP-8 (collagenase) and MMP-9 (gelatinase), in most 
cases, demonstrating the relationship of these MMPs with the periapical inflammatory process. These results agree with the finding of a recent study evaluated the periodontal and endodontic infectious/inflammatory profile in primary periodontal lesions with secondary endodontic involvement (21). In the same study, Duque et al. (21) suggested that the $\mathrm{Ca}(\mathrm{OH})_{2}$ paste is effective in reducing the MMP-3, MMP8, MMP-9 among others in endodontic and periodontal samples. In the present study, similar results present the capacity of $\mathrm{Ca}(\mathrm{OH})_{2}$ when associated with $\mathrm{CHX}$ in reducing the MMP-8 and MMP-9 levels in the root canal.

Takahama et al. (22) demonstrated in vivo the presence of MMP-2 and MMP-9 in the inflamed pulp and periapical tissue, indicating that MMP-2 and MMP-9 acts on pulpal and periapical inflammation. The presence of these MMPs in cases of necrosis pulp and periapical lesion plays a critical role in the pathogenesis of periapical lesions, probably involving the degradation of ECM during lesion development (8). In the same study Takahama et al. (22) detects higher levels of MMP-2 than MMP-9 in granulomas than in periapical cysts. However, both MMP-2 and MMP-9 were detected in granulomas and periapical cysts in which both play an important role in the active phase of soft and bone tissue destruction in apical periodontitis.

Various studies show the effectiveness of root canal treatment in reducing the MMPs levels in root canal $(12,21-23)$. In the present study the endodontic treatment is effective in reducing the MMP-8 and MMP-9 levels using the $\mathrm{NaOCl} 2.5 \%$ or even when associated with LW. The results of the current study also agree with a study by Paula-Silva et al. (24) evaluated in dogs the involvement of MMP-1, MMP-2, MMP-8 and MMP-9 during and after root canal treatment of apical periodontitis teeth. The authors verified high percentages of expression of MMP-1, MMP-2, MMP-8 and MMP-9 in teeth that did not receive endodontic treatment. However, the treatment of root canals with calcium hydroxide as MIC for 14 days promoted a lower percentage of bacterial contamination, lower expression of MMPs and more organized ECM compared to teeth treated in single session. These authors have argued that reduction of MMPs synthesis occurs in a calcium rich environment, so that calcium hydroxide may act as an inhibitor of MMPs activity in vivo.

In the present study, 2\% CHX + calcium hydroxide was used as intracanal medication, which was effective in providing low values of MMP-8 and MMP-9, as mentioned previously. The effects of $\mathrm{CHX}$ as an inhibitor of MMP-2, MMP-8 and MMP-9 activity have been clearly demonstrated in the study by Gendron et al. (25) in which the authors suggested that direct inhibition of MMPs activities by $\mathrm{CHX}$ may represent a valuable effect of this antimicrobial agent and explain, at least in part, the beneficial effects of $\mathrm{CHX}$ in the treatment of periodontitis. Even more, the calcium hydroxide as intracanal medication was effective in reducing the MMP-2, MMP-3, MMP-8, MMP-9 levels in apical periodontitis when associated with $2 \% \mathrm{CHX}$ gel as an irrigating agent (26). However, more recent study presents $\mathrm{CHX}$ as not effective in reducing the MMP-9 level, in which MMP-9 level increased after the endodontic treatment with $2 \% \mathrm{CHX}$, whereas $\mathrm{Ca}(\mathrm{OH})_{2}$ was effective (27). Thus, in this study, it was suggested the association of both $\mathrm{Ca}(\mathrm{OH})_{2}$ and $\mathrm{CHX}$ to gain the action of both medications over MMPs, in which this association was effective in reducing the MMP-8 and MMP-9 levels in the groups irrigated with $\mathrm{NaOCl}$ or $\mathrm{NaOCl}+$ LW.

Another point to emphasize is the activity of EDTA as an inhibitor of MMPs (28). In the present study, many cases present zero values of MMP-8 and MMP-9 after the 3rd collection. However, endodontic treatment uses different chemical substances (chlorhexidine, calcium hydroxide and EDTA) at different times with inhibitory activity on MMPs, which certainly contributes to the success of the treatment.

In an anterior study (16), evaluating the $\mathrm{NaOCl} 2.5 \%$ only and when associated with LW and PMB in reducing the LPS levels in apical periodontitis, it was concluded that the PMB when associated to $\mathrm{NaOCl}$ was effective in reducing LPS levels whereas the association of $\mathrm{Ca}(\mathrm{OH}) 2$ had no further effectiveness. However, in the present study, the $\mathrm{LW}$ when associated with $\mathrm{NaOCl}$ improves its effectiveness over MMPs levels. And the intracanal medication improves this ability especially over MMP-8 and MMP-9.

In this study the LW and PMB were used as irrigating agents associated with $2.5 \% \mathrm{NaOCl}$ but not separated because of its physical formula. The LW is a diluted solution of calcium hydroxide, and the PMB is an antibiotic in form of salt, so as a limitation of this study it was not possible to use these agents as solely irrigants and the suggestion of this study was to use these agents in intercalation with $\mathrm{NaOCl}$. This may affect the results of this study, as $\mathrm{NaOCl}$ may interfere positively or negatively in the actions of LW and PMB.

The complex correlation in the endodontic infection between bacteria, LPS, MMPs, cytokines and growth factors (19), in which each component has a role in this infection, make a conclusion unachievable. The results of the present study when associated with the anterior study (16) indicate PMB as an irrigating agent due to its effectivity in detoxifying LPS, and LW as well due to its effectivity in reducing MMPs levels. However, more studies should evaluate the association of both of them in terms of antimicrobial actions and cytotoxicity and genotoxicity.

It may be concluded that $\mathrm{NaOCl}$ and $\mathrm{NaOCl}+\mathrm{LW}$ are effective in reducing MMP-9 levels and the association of the intracanal medication $\left[\mathrm{Ca}(\mathrm{OH})_{2}+\mathrm{CHX}\right]$ with $\mathrm{NaOCl}$ or 
$\mathrm{NaOCl}+\mathrm{LW}$ is effective in reducing MMP-8 and MMP-9 levels.

\section{Resumo}

0 objetivo deste estudo foi avaliar o hipoclorito de sódio ( $\mathrm{NaOCl}$ ), água de cal (LW) e polimixina B (PMB) como soluções irrigadoras sobre MMP3, MMP-8 e MMP-9. Trinta e três pacientes com periodontite apical de dentes unirradiculares foram tratados de acordo com três grupos experimentais $(n=11)$ : grupo $1: 2,5 \% \mathrm{NaOCl}$ foi usado como solução irrigadora; grupo-2: $\mathrm{NaOCl}$ a 2,5\% para as duas primeiras limas e LW: $\left[0,14 \% \mathrm{Ca}(\mathrm{OH})_{2}\right]$ para as duas últimas limas; group-3: $2.5 \% \mathrm{NaOCl}$ para as duas primeiras limas e PMB para as duas últimas limas. A associação de $\mathrm{Ca}(\mathrm{OH})_{2}$ e $\mathrm{CHX}$ foi utilizada como medicação intracanal em todos os grupos. Quatro amostras de canais radiculares (S) foram coletadas: S1) imediatamente após a cirurgia de acesso; S2) após o preparo biomecânico; S3) após aplicação do EDTA; e S4) após a remoção da medicação intracanal. Após a quantificação das MMP-3, MMP-8 e MMP-9, os dados foram analisados pelos testes de Friedman e Kruskal-Wallis e completados pelo teste de Dunn (5\%). Independentemente da solução irrigadora utilizada, não houve diferença na redução de MMP-3 ou MMP-8 $(P=0,5273, P=$ 0,7048 respectivamente). No entanto, na redução de MMP-9 $(P=0,0246)$ o grupo $\mathrm{NaOCl}$ foi o mais eficaz, seguido pelo grupo $\mathrm{NaOCl}+\mathrm{LW}$ e grupo $\mathrm{NaOCl}+\mathrm{PMB}$, respectivamente. A medicação intracanal $[\mathrm{Ca}(\mathrm{OH}) 2+\mathrm{CHX}]$ com o $\mathrm{NaOCl}$ e $\mathrm{NaOCl}+\mathrm{LW}$ foi eficaz na redução de MMP-8 $(\mathrm{P}<0,0001$, $P=0,0025)$ e MMP-9 $(P=0,0007, P=0,0047)$ respectivamente, mas não para o grupo de $\mathrm{NaOCl}+\mathrm{PMB}$ que não foi eficaz na redução de MMP-8 ou MMP-9 $(P=0,1718, P=0,1953)$, respectivamente. $\mathrm{NaOCl}$ e $\mathrm{NaOCl}+\mathrm{LW}$ foram eficazes na redução dos níveis de MMP-9, e esta efetividade pode ser melhorada pelo uso da medicação intracanal $\left[\mathrm{Ca}(\mathrm{OH})_{2}+\mathrm{CHX}\right]$ na redução dos níveis de MMP-8 e MMP-9.

\section{References}

1. Mohammadi Z. Endotoxin in endodontic infections: a review. J Calif Dent Assoc. 2011;39:158.

2. Mergenhagen $\mathrm{SE}$, Varah E. Serologically specific lipopolysaccharides from oral veillonella. Arch Oral Biol 1963;8:31-36.

3. Knox KW. The potential role of bacteria and their antigens in periodontal disease. Aust Dent J 1976;21:397-404.

4. Stashenko P, Teles R, D'Souza R. Periapical inflammatory responses and their modulation. Crit Rev Oral Biol Med 1998;9:498-521.

5. Leonardo MR, Silva RAB da, Assed S, Nelson-Filho P. Importance of bacterial endotoxin (LPS) in endodontics. J Appl Oral Sci 2004;12:9398.

6. Dahlén G, Hofstad T. Endotoxic activities of lipopolysaccharides of microorgan-isms isolated from an infected root canal in Macaca cynomolgus. Scand J Dent Res 1977;85:272-278.

7. Hong C-Y, Lin S-K, Kok S-H, Cheng S-J, Lee M-S, Wang T-M, et al. The role of lipopolysaccharide in infectious bone resorption of periapical lesion. J Oral Pathol Med 2004;33:162-169.

8. Corotti MV, Zambuzzi WF, Paiva KBS, Menezes R, Pinto LC, Lara VS, et al. Im-munolocalization of matrix metalloproteinases-2 and -9 during apical periodontitis devel-opment. Arch Oral Biol 2009;54:764-771.

9. Woessner JF, Nagase H. Matrix Metalloproteinases and TIMPs - J. Frederick Woessner; Hideaki Nagase - Oxford University Press [Internet]. [cited 2019 Feb 22]. Available from: https://global.oup. com/academic/product/matrix-metalloproteinases-and-timps9780198502685 ?cc $=$ br\&lang=en \&

10. Sorsa T, Tjäderhane $L$, Salo T. Matrix metalloproteinases (MMPs) in oral diseases. Oral Dis 2004;10:311-318.

11. Cavalli D, Toia CC, Flores Orozco El, Khoury RD, Cardoso FG da R, Alves $M C$, et al. Effectiveness in the removal of endotoxins and microbiological profile in primary en-dodontic infections using 3 different instrumentation systems: A randomized clinical study. J Endod. 2017:43:1237-1245.

12. Martinho FC, Teixeira FFC, Cardoso FGR, Ferreira NS, Nascimento GG,
Carvalho CAT, et al. Clinical investigation of matrix metalloproteinases, tissue inhibitors of matrix metalloproteinases, and matrix metalloproteinase/tissue inhibitors of matrix metallopro-teinase complexes and their networks in apical periodontitis. J Endod 2016;42:1082-1088.

13. Oliveira LD, Leão MVP, Carvalho $C A T$, Camargo $C H R$, Valera $M C$, Jorge $\mathrm{AOC}$, et al. In vitro effects of calcium hydroxide and polymyxin $\mathrm{B}$ on endotoxins in root canals. J Dent 2005;33:107-114.

14. Oliveira LD de, Carvalho CAT, Carvalho AS, Alves J de S, Valera MC Jorge AOC. Efficacy of endodontic treatment for endotoxin reduction in primarily infected root canals and evaluation of cytotoxic effects. J Endod 2012;38:1053-1057.

15. de Oliveira LD, Jorge AOC, Carvalho CAT, Koga-Ito CY, Valera MC. In vitro ef-fects of endodontic irrigants on endotoxins in root canals. Oral Surg Oral Med Oral Pathol Oral Radiol Endod 2007;104:135-142.

16. Carvalho AS, Oliveira LD de, Cardoso FG da R, Oliveira FE de, Valera MC, Carva-Iho CAT. Limewater and Polymyxin B Associated with $\mathrm{NaOCl}$ for Endotoxin Detoxifica-tion in Root Canal with Necrotic Pulp. Braz Dent J 2016;27:573-577.

17. Gusman H, Santana RB, Zehnder M. Matrix metalloproteinase levels and gelatino-lytic activity in clinically healthy and inflamed human dental pulps. Eur J Oral Sci. 2002 0ct;110(5):353-357.

18. Menezes-Silva R, Khaliq S, Deeley K, Letra A, Vieira AR. Genetic susceptibility to periapical disease: conditional contribution of MMP2 and MMP3 genes to the development of periapical lesions and healing response. J Endod 2012;38:604-607.

19. Gomes BPF de A, Herrera DR. Etiologic role of root canal infection in apical perio-dontitis and its relationship with clinical symptomatology. Braz Oral Res 2018;32(suppl 1):e69.

20. Zanini $M$, Meyer $E_{1}$ Simon S. Pulp inflammation diagnosis from clinical to in-flammatory mediators: a systematic review. J Endod 2017:43:1033-1051.

21. Duque TM, Prado M, Herrera DR, Gomes BPFA. Periodontal and endodontic infec-tious/inflammatory profile in primary periodontal lesions with secondary endodontic in-volvement after a calcium hydroxide-based intracanal medication. Clin Oral Investig 2019;23:5363.

22. Takahama A, Rôças IN, Faustino ISP, Alves FRF, Azevedo RS, Gomes $\mathrm{CC}$, et al. Association between bacteria occurring in the apical canal system and expression of bone-resorbing mediators and matrix metalloproteinases in apical periodontitis. Int Endod J 2018;51:738746.

23. Pattamapun $K$, Handagoon $S$, Sastraruji $T$, Gutmann JL, Pavasant $P$, Krisanapra-kornkit S. Decreased levels of matrix metalloproteinase-2 in root-canal exudates during root canal treatment. Arch Oral Biol 2017 0ct;82:27-32.

24. Paula-Silva FWG, da Silva LAB, Kapila YL. Matrix metalloproteinase expression in teeth with apical periodontitis is differentially modulated by the modality of root canal treatment. J Endod 2010;36:231-237.

25. Gendron R, Grenier D, Sorsa T, Mayrand D. Inhibition of the activities of matrix metalloproteinases 2, 8, and 9 by chlorhexidine. Clin Diagn Lab Immunol 1999;6:437-439.

26. Barbosa-Ribeiro M, Arruda-Vasconcelos R, de-Jesus-Soares A, Zaia AA, Ferraz CCR, de Almeida JFA, et al. Effectiveness of calcium hydroxidebased intracanal medica-tion on infectious/inflammatory contents in teeth with post-treatment apical periodontitis. Clin Oral Investig 2018;23:1-8

27. Özdemir MB, Karatag E, Albayrak M, Bayır Y. Effect of intracanal medicaments on matrix metalloproteinase- 9 and vasoactive intestinal peptide secretion in periapical lesions of re-treated canals: a randomized controlled clinical study. Clin Oral Investig 2019;23:921928.

28. Thompson JM, Agee K, Sidow SJ, McNally K, Lindsey K, Borke J, et al. Inhibition of endogenous dentin matrix metalloproteinases by ethylenediaminetetraacetic acid. J Endod 2012;38:62-65. 